\title{
Short Communication: \\ Callus induction in purple and white-purple varieties of Orthosiphon aristatus (Blume) Miq.
}

\author{
FAHRAUK FARAMAYUDA ${ }^{1,2}$, TOTIK SRI MARIANI ${ }^{3}$, ELFAHMI ${ }^{1,4, \boldsymbol{v}}$, SUKRASNO $^{1}$ \\ ${ }^{1}$ School of Pharmacy, Institut Teknologi Bandung. Jl. Ganesa No. 10, Bandung 40132, West Java, Indonesia. \\ Tel/fax.: +62-22-6629821, •email: elfahmi@gmail.com, ramayuda.f@gmail.com \\ ${ }^{2}$ Faculty of Pharmacy, Universitas Jenderal Achmad Yani. Jl. Terusan Jend. Sudirman, Cimahi 40531, West Java, Indonesia \\ ${ }^{3}$ School of Life Sciences and Technology, Institut Teknologi Bandung. Jl. Ganesa No. 10, Bandung 40132, West Java, Indonesia \\ ${ }^{4}$ Biosciences and Biotechnology Research Center, Institut Teknologi Bandung. Jl. Ganesa No. 10, Bandung 40132, West Java, Indonesia
}

Manuscript received: 7 August 2020. Revision accepted: 30 September 2020.

\begin{abstract}
Faramayuda F, Mariani TS, Elfahmi, Sukrasno. 2020. Short Communication: Callus induction in purple and white-purple varieties of Orthosiphon aristatus (Blume) Miq. Biodiversitas 21: 4967-4972. Orthosiphon aristatus (Blume) Miq. are known to have many benefits, including stimulating urine expenditure (diuretics) and dissolving kidney stones. $O$. aristatus widely planted in Indonesia are purple and white-purple. The main secondary metabolite components of $O$. aristatus are sinensetin, rosmarinic acid, and eupatorin. One of the initial steps to increase secondary metabolites in $O$. aristatus is by induction of callus using plant tissue, which later can be developed into a culture suspension for secondary metabolites. The materials used are the leaf of two varieties of $O$. aristatus that have been sterilized and grown on Murashige and Skoog media with growth regulatory 2,4-dichlorophenoxyacetic acid at a concentration of $0.4 ; 1.0 ; 2.0 \mathrm{mg} / \mathrm{L}$. The identification of secondary metabolites of callus was carried out by thin-layer chromatography. The best growth regulating agent for callus induction on the leaves of purple and white-purple varieties of $O$. aristatus is $2,4-\mathrm{D} 0.4 \mathrm{mg} / \mathrm{L}$ on Murashige and Skoog media. These media can grow callus at a faster time, friable, and slightly white-yellow color. The identification of secondary metabolites in callus acetone extract showed the presence of sinensetin and rosmarinic acid.
\end{abstract}

Keywords: 2,4-D, growth regulatory, Orthosiphon aristatus, plant tissue culture, secondary metabolites identification, variety

\section{INTRODUCTION}

Orthosiphon aristatus is a plant that can be used as traditional medicinal ingredients, cosmetics, and supplements. Pharmacological activities of $O$. aristatus have been tested pra-clinically and clinically. Some of the plant's pharmacological activities include antidiabetic (Mohamed et al. 2011), treatment gastric disorders (Yuniarto et al. 2017), antiviral (Ripim et al. 2018), prevention and treatment cancer (Pauzi et al. 2018; Halim et al. 2017; Abdelwahab et al. 2011), rheumatoid arthritis treatment (Bokhari et al. 2018), treatment cardiovascular disorders (Abraika et al. 2012), antioxidants (Alshawsh et al. 2012), enhancing memory (George et al. 2015), antiepilepsy (Kar et al. 2018), and antimicrobial activity (Ho et al. 2010). O.aristatus have passed clinical trials for the treatment of hypertension and kidney disorders (Adnyana et al. 2013). The water extract of $O$. aristatus did not cause signs of toxicity in pregnant mice (Muhammad et al. 2013).

The content of the main secondary metabolite compounds in $O$. aristatus is rosmarinate acid, eupatorin, and sinensetin (Guo et al. 2019). Sinensetin and eupatorin are included in the class of flavonoid compounds and if they are classified, more specifically are polymethoxy compounds produced by secretory tissue and stored inside or outside the oil glands in plants. Flavone polymethoxy compounds have several pharmacological activities in vitro and in vivo and are part of the plant chemical defense mechanism (Berim and Gang 2016). Rosmarinic acid has excellent antioxidant activity (Amoah et al. 2015). $O$. aristatus that grow in Indonesia are classified into three varieties: purple, intermediate (white-purple), and white. The difference between the three varieties can be seen from the flower's color. The purple variety's crown color is purple, and the white variety is white (Febjislami et al. 2019). O. aristatus are propagated through cuttings and seeds, culture techniques such as plant cell suspension cultures, and alternative ways to produce plants with uniform quality and quantity of secondary metabolites.

This research provides new information about the comparison of callus induction of two varieties of $O$. aristatus and determines the content of secondary metabolites of the formed callus. A callus with a good profile will be used to make culture suspensions for the production of active secondary metabolites.

\section{MATERIALS AND METHODS}

\section{Collection and identification of authenticity}

Purple and white-purple variety of Orthosiphon aristatus, which will be observed for morphology, are obtained from Manoko Lembang Experimental Garden in West Bandung District, Indonesia. The sampling time is 
February 2019. The leaves and stems of the $O$. aristatus used for the extraction process are then washed with running water, drying in an oven at $50{ }^{\circ} \mathrm{C}$ for three days, and grinding the dry ingredients to obtain a crude drug powder. Determination of the two varieties of $O$. aristatus to determine the correctness of its type at the School of Biological Science and Technology, Institut Teknologi Bandung (ITB). The plant identification number is 6115/I1.CO2.2/PL/2019.

\section{Morphological studies}

Observation of plant morphology of two varieties of $O$. aristatus includes plant height, stem characters (diameter, circumference, and color), leaf characters (base, tip, edge, length, width, stem length, and color), and flower characters (stalk length, crown color, pistil color, stamen color, number of crowns, number of stamens, flower stalk length, flower diameter, and petal color.

\section{Extraction}

A number of $100 \mathrm{~g}$ of leaves and stems of two varieties of $O$. aristatus were transferred to macerators, and each of them macerated with $1.5 \mathrm{~L}$ of ethanol $96 \%$ then macerated for 24 hours. The filtrate was collected and evaporated using a rotary evaporator.

\section{Phytochemical screening}

The secondary metabolite identification of the crude ethanolic extract of leaves and stems $O$. aristatus are alkaloids, flavonoids, quinones, tannins, polyphenols, saponins, steroids and triterpenes, monoterpenoids, and sesquiterpenoids.

\section{Callus culture medium}

The medium used in this study was Murashige and Skoog (Phytotechlab®). The media is conditioned at a $\mathrm{pH}$ of 5.7-5.8. Media sterilization was carried out using an autoclave at a temperature of $121^{\circ} \mathrm{C}$ for 15 minutes. The induction process was carried out in a laminar airflow cabinet that had been previously sterilized using $70 \%$ alcohol and exposed to UV light for 30 minutes.

\section{Optimization of plant leaf sterilization}

Leaf explants were washed first with running water for 15 minutes, in $70 \%$ ethanol for 1 minute, and immersed for 5 minutes in $\mathrm{NaOCl}$ solution plus two drops of Tween 80 . Explant rinsed with sterile water three times for 1 minute each. The explants were then transferred to sterile Petri and planted on solid MS media.

\section{Callus induction}

The media used is MS solid media and added growth regulator 2,4-D with a concentration of $0.4 ; 1 ; 2 \mathrm{mg} / \mathrm{L}$ (each concentration is five repetitions). The culture bottle is stored on a culture rack. The culture bottles were stored in the incubation room with a Philips 36 Watt lamp illuminated for 8 hours and 16 hours of darkness at a temperature of $19-20^{\circ} \mathrm{C}$.

\section{Callus extraction and plant samples of two varieties Orthosiphon aristatus}

The calluses formed (PC1 and WPC1) were separated from the medium and dried in an oven at $70^{\circ} \mathrm{C}$. Several one grams of fine powder of callus and raw material of leaves and stems of two varieties of $O$. aristatus were extracted separately by maceration using acetone, ethyl acetate, and ethanol. The extract was concentrated and ready to be bottled on a silica gel 60 F254 plates.

\section{Analysis of callus extracts with thin layer chromatography (TLC)}

The callus and thick extracts (leaves and stem) of two varieties of $O$. aristatus were diluted using methanol, then applied on silica gel 60 F254 plates. The mobile phase used was chloroform: ethyl acetate 60:40 (Hossain and Ismail. 2016) and toluene-ethyl acetate-formic acid-water 3: 3: 1: 0.2 (Craciun et al. 2014). The mobile phase is saturated in a closed TLC tank for 20 minutes. TLC profile analysis was performed under short and long-wave UV light.

\section{Data analysis}

Callus induction at each concentration of growth regulators was done five times. Data presentation is expressed as mean \pm standard deviation. Processing was done using one-way ANOVA, then tested by Duncan using SPSS 22 software. When the P-value $<0.05$ was considered a significant difference.

\section{RESULTS AND DISCUSSION}

\section{Morphological studies}

In the morphological observation, the most fundamental difference in the two varieties of O.aristatus is flower morphology. The crown's color is purple in purple varieties, while in white-purple varieties, the crown has a purple tinge. (Table 1; and Figure 2). The determination results at the School of Biological Science and Technology, Institut Teknologi Bandung (ITB), two plant samples included purple and white-purple flower $O$. aristatus.

Table 1. Observation of the morphology of purple and white purple varieties

\begin{tabular}{lll}
\hline \multicolumn{1}{c}{ Observation } & $\begin{array}{c}\text { Purple variety } \pm \\
\text { SD }(\mathbf{n}=\mathbf{3})\end{array}$ & $\begin{array}{c}\text { White-purple } \\
\text { variety } \pm \text { SD }(\mathbf{n = 3})\end{array}$ \\
\hline Color of the stem & Purple & Green \\
Leaf base & Asymmetry & Asymmetry \\
Leaf tip & Pointed & Pointed \\
leaf edge & Align & Align \\
Leaf color & Dark green & Light green \\
Petal color & Green-purple & Green \\
Crown color & Purple & White \\
Color of the stems of the pistil & Purple & White-purple \\
Color of stamens & Purple & White-purple \\
Plant height nine months $(\mathrm{cm})$ & $62 \pm 0.1$ & $75 \pm 0.1$ \\
Stem circumference $(\mathrm{cm})$ & $1 \pm 0.05$ & $1.2 \pm 0.05$ \\
Rod diameter $(\mathrm{cm})$ & $0.25 \pm 0$ & $0.25 \pm 0.05$ \\
Leaf Length $(\mathrm{cm})$ & $4.33 \pm 0.12$ & $4.36 \pm 0.28$ \\
Petiole length $(\mathrm{cm})$ & $0.83 \pm 0.23$ & $0.73 \pm 0.02$ \\
Number of crowns & $2.0 \pm 0.00$ & $2.0 \pm 0.00$ \\
Number of stamens & $5.0 \pm 0.00$ & $5.0 \pm 0.00$ \\
Flower stem length $(\mathrm{cm})$ & $0.4 \pm 0.00$ & $0.41 \pm 0.02$ \\
Flower Diameter $(\mathrm{cm})$ & $1.1 \pm 0.00$ & $1.1 \pm 0.00$ \\
\hline
\end{tabular}




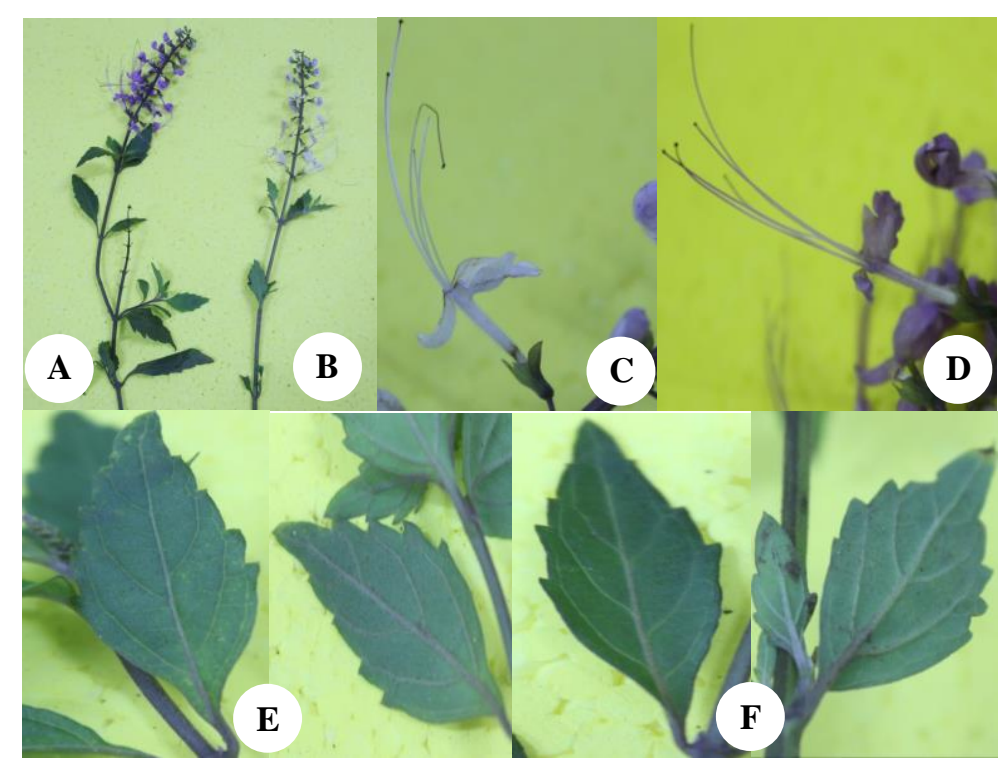

Figure 2. Observation of the morphology of two varieties of Orthosiphon aristatus. A. Purple variety, B. white-purple variety, C. the flower of purple variety, D. the flower of white-purple variety, E. the leaf of purple variety, F. the leaf of white-purple variety

\section{Callus induction}

Callus optimization results at all variations of 2,4-D concentration $0.4 ; 1.0 ; 2.0 \mathrm{mg} / \mathrm{L}$ showed the formation of callus from two varieties of $O$. aristatus, but at a concentration of $0.4 \mathrm{mg} / \mathrm{L}$, the callus was formed faster and produce greater callus dry weight than the concentrations of $1.0 ; 2.0 \mathrm{mg} / \mathrm{L}$ (Table 3). callus white-purple varieties at a concentration of 2,4-D $0.4 \mathrm{mg} / \mathrm{L}$ formed faster than purple varieties in terms of white-purple callus producing callus brownish-white with a brittle texture. Based on statistical data, there was no significant difference in dry callus weight between WPC2 and WPC3 (Figures 3 and 4).

The Murashige and Skoog media, known as MS, contain $40 \mathrm{mM}$ nitrogen in $\mathrm{NO}_{3}$ and $29 \mathrm{mM} \mathrm{NH}_{4}^{+}$. Several previous studies reported callus induction in a variety of $O$. aristatus on MS base media with several growth regulating compositions including MS + NAA $1 \mathrm{mg} / \mathrm{L}+2,4-\mathrm{D} 1$ $\mathrm{mg} / \mathrm{L}$ (Bordbar et al. 2015); $\mathrm{MS}+1.0 \mathrm{mg} / \mathrm{L}$ Kinetin +1.0 $\mathrm{mg} / \mathrm{L} \mathrm{IAA}$ and $\mathrm{MS}+2 \mathrm{mg} / \mathrm{L}$ 2,4-D (Ali et al. 2017). This study provides new information about the optimum concentration of growth regulators in growing two callus varieties of cats.

One of the auxin group growth regulators is 2,4dichlorophenoxyacetic acid. The usage of 2,4-D in inducing callus in other plants such as Coelogyne cristata (Naing et al. 2011). An addition of $0.5 \mathrm{mg} / \mathrm{L}$ 2,4-D can induce $P$. niveum callus (Chaireok et al. 2015). Callus induction of A. odorata (Devi et al. 2013) and Vanda sumatrana (Astuti et al. 2016) can be formed by adding 2,4-D $2 \mathrm{mg} / \mathrm{L}$. The addition of 2,4-D $0.25 \mathrm{mg} / \mathrm{L}$ was able to induce callus on leaf explants of A. vulgaris (Fadhilah et al. 2015).<smiles>O=C(O)/C=C/c1ccc(O)c(O)c1</smiles>

Rosmarinic acid<smiles>COc1ccc(-c2cc(=O)c3c(O)c(O)c(O)cc3o2)cc1O</smiles>

Eupatorine<smiles>COc1ccc(-c2cc(=O)c3c(O)c(OC)c(OC)cc3o2)cc1O</smiles>

Sinesetin

Figure 1. Chemical structure of rosmarinic acid, eupatorin, and sinensetin 
Table 2. The results of phytochemical screening for crude drugs and extracts Orthosiphon aristatus

\begin{tabular}{|c|c|c|c|c|c|c|c|c|}
\hline \multirow{2}{*}{ Compound group } & \multicolumn{4}{|c|}{ Crude drugs powder } & \multicolumn{4}{|c|}{ Ethanol extract } \\
\hline & LP & SP & LWP & SWP & LP & SP & LWP & SWP \\
\hline Alkaloid & + & + & + & + & + & + & + & + \\
\hline Flavonoid & + & + & + & + & + & + & + & + \\
\hline Tannin & + & + & + & + & + & + & + & + \\
\hline Polyphenolic & + & + & + & + & + & + & + & + \\
\hline Quinone & - & - & - & - & - & - & - & - \\
\hline Saponin & + & + & + & + & + & + & + & + \\
\hline Steroid \& triterpenoid & + & + & + & + & + & + & + & + \\
\hline Monoterpenoid \& sesquiterpenoid & + & + & + & + & + & + & + & + \\
\hline
\end{tabular}

Note: (+) positive; (-) negative. LP: leaf of purple variety, SP: stem of purple variety, LWP: leaf of white-purple variety, SWP: stem of white-purple variety

Table 3. Callus induction optimization results in two varieties of Orthosiphon aristatus

\begin{tabular}{|c|c|c|c|c|c|}
\hline Growth regulator & $\begin{array}{l}\text { Time formed callus } \\
\text { (days) } n=5 \pm \text { SD }\end{array}$ & $\begin{array}{l}\text { Texture } \\
\text { (14 days) }\end{array}$ & $\begin{array}{c}\text { Color } \\
(14 \text { days })\end{array}$ & $\begin{array}{c}\text { Callus response }(\%) \\
N=5 \pm \text { SD }\end{array}$ & $\begin{array}{c}\text { Dry weight (g) } \\
\mathbf{N}=5 \pm \mathrm{SD}\end{array}$ \\
\hline \multicolumn{6}{|l|}{ Purple variety } \\
\hline $\mathrm{MS}+2,4-\mathrm{D} 0.4 \mathrm{mg} / \mathrm{L}$ & $9 \pm 0,00$ & Friable & White-yellow & $100 \pm 0.00$ & $2.00 \pm 0,06^{(a)}$ \\
\hline $\mathrm{MS}+2,4-\mathrm{D} 1.0 \mathrm{mg} / \mathrm{L}$ & $9 \pm 0,00$ & Semi friable & White-brown & $100 \pm 0.00$ & $0,92 \pm 0,12^{(b)}$ \\
\hline $\mathrm{MS}+2,4-\mathrm{D} 2 \mathrm{mg} / \mathrm{L}$ & $12 \pm 0,0$ & Semi friable & White-brown & $100 \pm 0.00$ & $1,32 \pm 0,03^{(\mathrm{c})}$ \\
\hline \multicolumn{6}{|l|}{ White-purple variety } \\
\hline $\mathrm{MS}+2,4-\mathrm{D} 0.4 \mathrm{mg} / \mathrm{L}$ & $6 \pm 0,00$ & Friable & White-yellow & $100 \pm 0.00$ & $2.40 \pm 0,01^{(\mathrm{d})}$ \\
\hline $\mathrm{MS}+2,4-\mathrm{D} 1.0 \mathrm{mg} / \mathrm{L}$ & $10 \pm 0,47$ & Semi friable & White-brown & $100 \pm 0.00$ & $1,56 \pm 0,15^{(\mathrm{e})}$ \\
\hline $\mathrm{MS}+2,4-\mathrm{D} 2.0 \mathrm{mg} / \mathrm{L}$ & $12 \pm 0,94$ & Semi friable & White-brown & $100 \pm 0.00$ & $1,61 \pm 0,03^{(\mathrm{e})}$ \\
\hline
\end{tabular}

Note: The mean value with superscript letters shows a significant difference $(\mathrm{p}<0.05)$

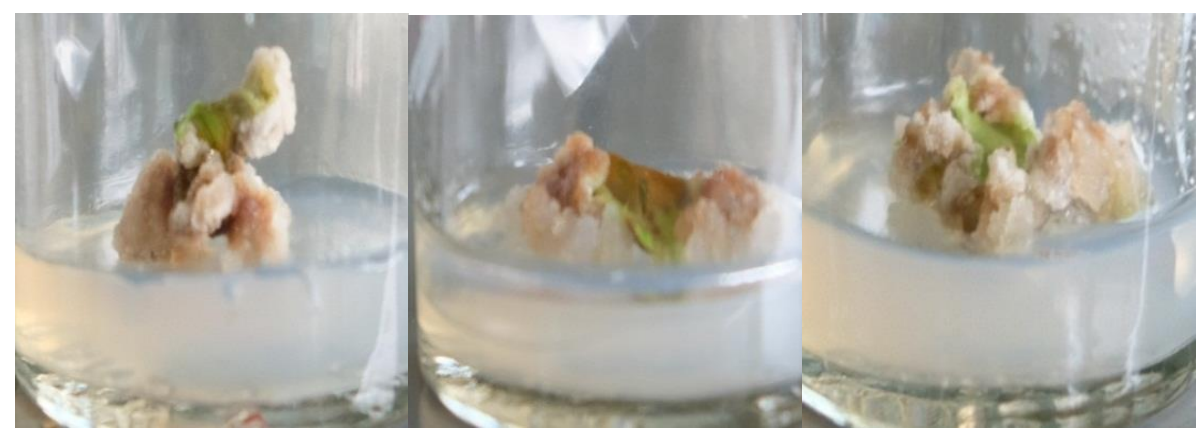

Figure 3. Callus of white-purple varieties Orthosiphon aristatus. A. White-purple callus with 2,4-D 0.4 mg/L (WPC1), B. White-purple callus with 2,4-D $1 \mathrm{mg} / \mathrm{L}$ (WPC2), C. White-purple callus with 2,4-D $2 \mathrm{mg} / \mathrm{L}$ (WPC3).

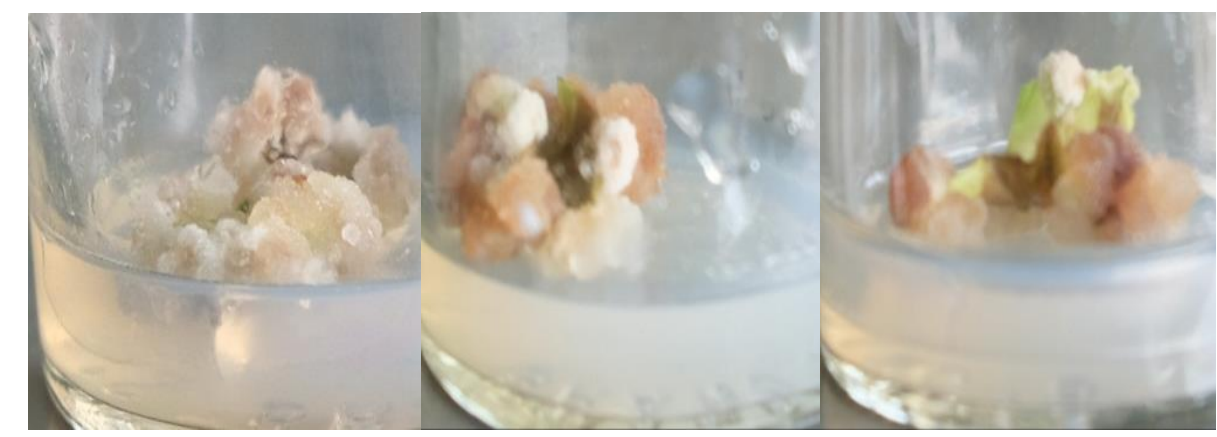

Figure 4. Callus of purple variety Orthosiphon aristatus. A. Purple callus with 2,4-D 0,4 mg/L (PC1), B. Purple callus with 2,4-D 1 mg/L (PC2), C. Purple callus with 2,4-D 2 mg/L (PC3) 


\section{Analysis of secondary metabolite of callus extracts}

Observation of secondary metabolites of callus extract compared with leaf and stem extracts of two varieties of $O$. aristatus using TLC showed the presence of sinensetin compounds in ethanol and acetone extract purple callus variety (Figure 4), whereas rosmarinic acid compounds detected in acetone extract purple callus varieties (Figure 5). In the white-purple callus, the spots of sinensetin and rosmarinic acid were not so bright, while in the purple varieties, spots sinensetin and rosmarinic acid were more

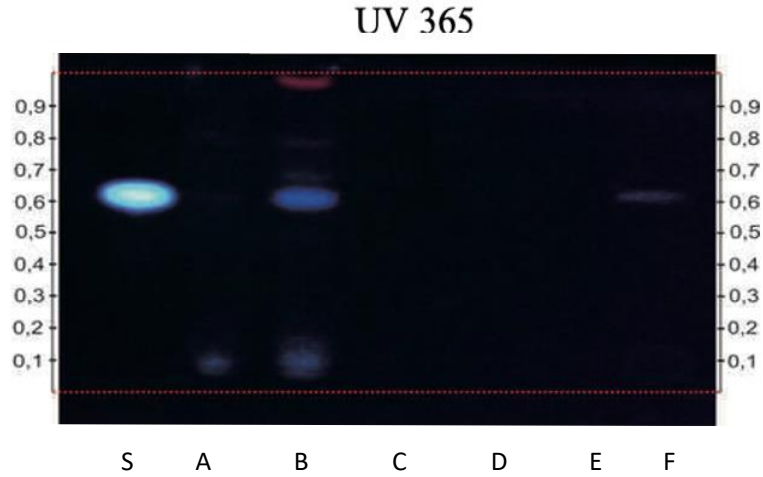

visible. These results indicate that the content of sinensetin and rosmarinic acid in purple callus varieties is higher than the white-purple callus. In the observation of the TLC profile using mobile phase toluene-ethyl acetate-formic acid-water 3: 3: 1: 0.2 (Craciun et al. 2014), the acetone extract of purple and white-purple callus varieties was found on Rf 0.71 in blue color where the spots were not found in the extract original plant leaves and stems, further identification of the compound at $\mathrm{Rf} 0.71$ is required (Figure 6 and Figure 7).

\section{UV 254}

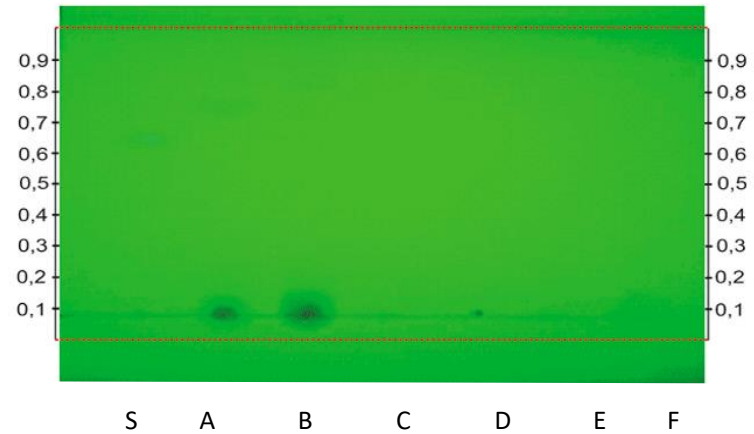

Figure 5. TLC profile of callus two varieties of Orthosiphon aristatus. Sinensetin (S), acetone extract of WPC1 (A), acetone extract of purple callus PC1 (B), ethyl acetate extract of WPC1 (C), ethyl acetate extract of PC1 (D), ethanol extract WPC1 (E), ethanol extract of PC1 (F). Silica gel 60 GF254 (stationary phase) and chloroform: ethyl acetate 60:40 (mobile phase).

UV 365



UV 254

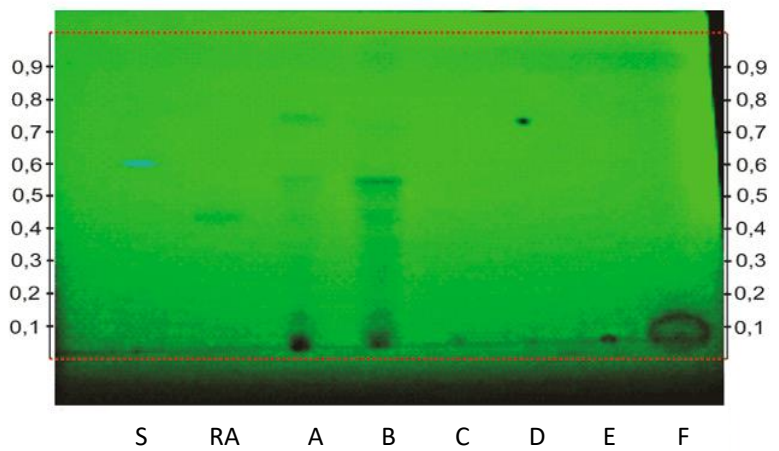

Figure 6. TLC profile of callus two varieties of Orthosiphon aristatus. Sinensetin (S), rosmarinic acid (RA), acetone extract of WPC1 (A), acetone extract of PC1 (B), ethyl acetate extract of WPC1 (C), ethyl acetate extract of PC1 (D), ethanol extract of WPC1 (E), ethanol extract of PC1 (F). Silica gel 60 GF254 (stationary phase) and toluene-ethyl acetate-formic acid-water (mobile phase).

UV 365

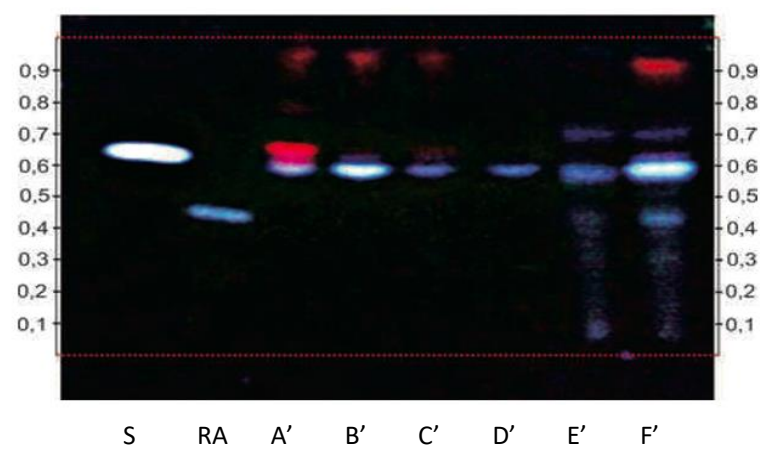

UV 254



Figure 7. Comparison of TLC profiles of leaf and stem acetone extract with callus extracts of two Orthosiphon aristatus. Sinensetin (S), rosmarinic acid (RA), acetone extract of white-purple leaf (A'), acetone extract of purple leaf (B'), acetone extract of white-purple stem $\left(C^{\prime}\right)$, acetone extract of purple stem (D'), acetone extract of WPC1 (E'), acetone extract of PC1 (F'). Silica gel 60 GF254 (stationary phase) and toluene ethyl acetate-formic acid-water phase (mobile phase) 
In conclusion, the growth regulator 2,4Dichlorophenoxyacetis acid $0.4 \mathrm{mg} / \mathrm{L}$ can grow callus of two varieties of $O$. aristatus. sinensetin and rosmarinic acid were detected in callus $O$. aristatus of purple varieties.

\section{ACKNOWLEDGEMENTS}

This research was funded by the Indonesian Ministry of Research and Technology/National Agency for Research and Innovation with contract number 2/E1/KP.PTNBH/ 2020 .

\section{REFERENCES}

Abdelwahab SI, Mohan S, Elhassan MM, Al-Mekhlafi N, Mariod AA, Abdul AB, Abdulla MA, Alkharfy KM. 2011. Antiapoptotic and antioxidant properties of Orthosiphon stamineus Benth (Cat's Whiskers): Intervention in the Bcl-2-Mediated apoptotic pathway. Evid Based Complement Alternat Med 2011: 156765. DOI: $10.1155 / 2011 / 156765$.

Abraika OSS, Atangwho IJ, Sadikun A, Asmawi MZ, Hussain EA. 2012. In vitro activity-guided vasodilatory effect of Orthosiphon stamineus leaves. J Exp Integr Med 2 (3): 255-261.

Adnyana IK, Setiawan F, Insanu M. 2013. From ethnopharmacology to clinical study of Orthosiphon stamineus Benth. Intl J Pharm Pharm Sci 5 (3): 66-73.

Ali H, Karsani SA, Othman R, Yaacob JS. 2017. Production of coloured callus in Orthosiphon stamineus Benth and antioxidant properties of the extracted pigments. Pigment Resin Technol 47 (11). DOI: 10.1108/PRT-01-2017-0009

Alshawsh M, Abdulla M, Ismail S, Amin Z, Qader SA, Hadi H, Harmal, N. 2012. Free radical scavenging, antimicrobial and immunomodulatory activities of Orthosiphon stamineus. Molecules 17 (5): 5385-5395. DOI: 10.3390/molecules 17055385

Amoah SK, Sandjo LP, Kratz JM, Biavatti MW. 2016. Rosmarinic acidpharmaceutical and clinical aspects. Planta Med 82: 388-406.

Astuti AT. 2016 Induction of somatic embryogenesis in Vanda sumatrana Schltr. with various concentrations of 2,4-Dichlorophenoxyacetic acid (2,4-D). [Thesis]. Universitas Andalas, Padang, Indonesia. [Indonesian]

Berim A, Gang DR. 2016. Methoxylated Flavones: Occurrence, Importance, Biosynthesis, Phytochemistry Reviews. Springer, Netherlands.

Bokhari RA, Tantowi NACA, Lau SF, Mohamed S. 2018. Java tea (Orthosiphon stamineus) protected against osteoarthritis by mitigating inflammation and cartilage degradation: A preclinical study. Inflammopharmacology 26 (4): 939-949. DOI: 10.1007/s10787-0170432-2

Bordbar L, Subramaniam S, Jelodar NB, Chan LK. 2015. Effects of abiotic factors on cell biomass and rosmarinic acid production in cell suspension cultures of Orthosiphon stamineus Benth. Emirates J Food Agric 27 (10): 756-762.

Craciun M, Cretu G, Miricioiu M, Birloiu A, Clej DD, Nechifor A. 2014 Identification, separation and quantification of rosmarinic acid from extract of Orthosiphon by HPTLC. Revista de Chimie 65: 621-626.

Chaireok S. 2015. Cryopreservation of protocorm-like bodies and callus of Lady's slipper orchids (Paphiopedilum niveum (Rchb.f.) Stein) by vitri-vication and encapsulation vitri-vication. [Thesis]. Songkla University, Songkhla, Thailand.

Devi HS, Devi SI, Singh TD. 2013. High-frequency plant regeneration system of Aerides odorata Lour. through foliar and shoot tip culture. Horti Agrobo 41 (1): 169-176.

Fadhilah N, Noli ZA, Suwirmen. 2015. Callus induction of Artemisia vulgaris $\mathrm{L}$. by giving some concentrations of 2,4 Dichloro-phenoxy acetic acid (2,4-D). Jurnal Biologi Universitas Andalas 4 (4): 216222. [ndonesian]

Febjislami S, Kurniawati A, Melati M, Wahyu Y. 2019. Morphological characters, flowering and seed germination of the Indonesian medicinal plant Orthosiphon aristatus. Biodiversitas 20 (2): 328-337. DOI: 10.13057/biodiv/d200204

George A, Chinnappan S, Choudhary Y, Choudhary V K, Bommu P, Wong HJ. 2015. Effects of a proprietary standardized Orthosiphon stamineus ethanolic leaf extract on enhancing memory in Sprague Dawley rats possibly via blockade of adenosine A 2 A receptors. Evid Based Complement Alternat Med 2015: 375837. DOI: $10.1155 / 2015 / 375837$

Guo Z, Liang X, Xie Y. 2019. Qualitative and quantitative analysis on the chemical constituents in Orthosiphon stamineus Benth. using ultrahigh-performance liquid chromatography coupled with electrospray ionization tandem mass spectrometry. J Pharm Biomed Anal 164: 135-147. DOI: 10.1016/j.jpba.2018.10.023

Halim NH, Pauzi N, Hamil SHR, Shafaei A, Ismail Z, Mohd KS. 2017. Standardization of Orthosiphon stamineus raw material and extracts for anti-uterine fibroid. Intl J Pharmacogn Phytochem Res 9 (4): 512515.

Ho C, Noryati I, Sulaiman S, Rosma A. 2010. In vitro antibacterial and antioxidant activities of Orthosiphon stamineus Benth. extracts against food-borne bacteria. Food Chem 122 (4): 1168-1172. DOI: 10.1016/j.foodchem.2010.03.110

Hossain MA, Ismail Z. 2016. Quantification and enrichment of sinensetin in the leaves of Orthosiphon stamineus. Arabian J Chem 9 (2): S1338-S1341. DOI: 10.1016/j.arabjc.2012.02.016

Kar B, Choo M, Kundap UP, Kumari Y, Hue S, Othman I, Shaikh MF. 2018. Orthosiphon stamineus leaf extract affects TNF- $\alpha$ and Seizures in a zebrafish model. Front Pharmacol 9: 139. DOI: 10.3389/fphar.2018.00139

Mohamed E, Mohamed AJ, Abdullah M, Sadikun A, Saad Ebrika O, Yam M. 2011. Antihyperglycemic effect of Orthosiphon Stamineus Benth leaves extract and its bioassay-guided fractions. Molecules 16 (5): 3787-3801. DOI: 10.3390/molecules16053787

Muhammad H, Sulaiman SA, Ismail Z, Paumgartten FJR. 2013. Study on the developmental toxicity of a standardized extract of Orthosiphon stamineus in rats. Revista Brasileira de Farmacognosia 23 (3): 513520. DOI: 10.1590/S0102-695X2013005000039

Naing AH, Chung JD, Lim KB. 2011. Plant regeneration through indirect somatic embryogenesis in Coelogyne cristata orchid. Am J Plant Sci 2: 262-267. DOI: 10.4236/ajps.2011.22028

Pauzi N, Mohd KS, Abdul Halim NH, Ismail Z. 2018. Orthosiphon stamineus extracts inhibit proliferation and induces apoptosis in uterine fibroid cells. Asian Pac J Cancer Prev 19 (10): 2737-2744. DOI: 10.22034/APJCP.2018.19.10.2737

Ripim M, Fazil N, Ibrahim K, Bahtiar A, Wai C, Ibrahim N, Nor M. 2018. Antiviral properties of Orthosiphon stamineus aqueous extract in Herpes Simplex Virus Type 1 infected cells. Sains Malaysiana 47 (8): 1725-1730.

Yuniarto ARI, Susilawati E, Khairunnisa I, Juanda D, Setiawan F. 2017. Antioxidant and gastric ulcer healing effect of Orthosiphon Stamineus (Benth.) leaves extract in aspirin-induced rats. Asian J Pharm Clin Res 10 (2): 2-4. 